\title{
PENGARUH BRAND IMAGE DAN LABEL HALAL TERHADAP KEPUTUSAN PEMBELIAN KOSMETIK WARDAH PADA MAHASISWI JURUSAN EKONOMI SYARIAH FAKULTAS EKONOMI DAN BISNIS ISLAM IAIN PADANGSIDIMPUAN
}

\author{
Yusnita Siregar ${ }^{1}$ Muhammad Isa ${ }^{2}$ Hamni Fadlilah Nasution ${ }^{3}$ \\ ${ }^{1}$ Mahasiswa IAIN Padangsidimpuan \\ ${ }^{2,3}$ Dosen IAIN Padangsidimpuan
}

\begin{abstract}
Students from the Islamic Economics Department, Faculty of Economics and Islamic Business, IAIN Padangsidimpuan, must be careful in choosing choices from various cosmetic brands that have good quality and brand image. Female students must be able to distinguish cosmetic products that are officially labeled halal and unofficial halal labels from the Indonesian Ulema Council for consumption. The formulation of the problem from this study is whether brand image and halal label have a partial and simultaneous effect on wardah cosmetic purchasing decisions on Islamic economics students from the faculty of economics and Islamic business at IAIN Padangsidimpuan. The purpose of this study is to determine the effect of halal brand image and label partially and simultaneously on wardah cosmetic purchasing decisions on Islamic economics students from the faculty of economics and Islamic business at IAIN Padangsidimpuan. The discussion in this study relates to the field of marketing. In this connection the approach taken is theories relating to brand image, halal label and purchasing decisions and certain parts of the science. This research is a quantitative study that uses data calculations using statistical calculations with the help of SPSS version 22. Population in this study are all the number of students in Islamic economics majoring in Islamic Economics and Business IAIN at the level of 788 people and a sample of 89 people. Data analysis techniques are multiple linear regression, classic assumption test, coefficient of determination, $t$ test and $F$ test. The results of the research obtained partially have an effect on the brand image of cosmetic purchasing decisions as evidenced by the value of $t$ count $>t$ table (4.497> 1.663). For the halal label variable also has an influence on cosmetic purchasing decisions as evidenced by tcount> t table (2.970>1.663). Based on the simultaneous results obtained by the value of Fcount> Ftable (20.583> 2.37), it can be concluded that there is a significant effect between the variable brand image and halal label on cosmetic purchasing decisions, with the coefficient of determination, the adjusted R2 value of 0.308 or 30, 8\%, indicating the brand image and halal label variables influence purchasing decisions and the remaining $69.2 \%$ is influenced by other factors beyond the research conducted by the researcher.
\end{abstract}

Keywords: Brand Image, Halal Label, and Purchasing Decision 


\section{PENDAHULUAN}

Kebutuhan wanita untuk terlihat menarik menciptakan potensi pasar yang sangat besar di industri kosmetik. Dalam keseharian, seorang wanita tidak bisa lepas dari kosmetik. Dengan kosmetik, wanita akan lebih percaya diri dan dipermudahkan dengan munculnya produkproduk kosmetik yang lebih simpel dan praktis untuk menunjang penampilannya dalam beraktivitas baik di dalam rumah maupun di luar rumah.

Apabila seorang konsumen memilih salah satu dari berbagai merek dan memutuskan untuk membeli suatu produk yang sesuai dengan keinginan, maka konsumen tersebut sudah melakukan keputusan pembelian. Konsumen merupakan seorang pelanggan, pemakai, pengguna, pembeli, dan pengambil keputusan. ${ }^{1}$ Mahasiswi selaku konsumen tentunya mempertimbangkan banyak hal untuk membeli produk kosmetik.

Keputusan untuk membeli barang dan jasa tertentu terkadang merupakan hasil dari proses yang lama dan rumit yang mencakup kegiatan mencari informasi, membandingkan berbagai merek, melakukan evaluasi, dan kegiatan lainnya. Namun terhadap produk lainnya, keputusan pembelian dapat terjadi secara mendadak, mungkin hanya dengan melihat produk tersebut dipajang di pasar swalayan dengan harga diskon. Sering ditemui, bahwa konsumen cepat membeli suatu produk karena dorongan hati yang muncul saat itu. ${ }^{2}$ Dalam proses keputusan pembelian konsumen dipengaruhi oleh beberapa faktor, antara lain faktor pribadi, faktor psikologis, dan faktor sosial.

Setiap perusahaan hendaknya mengembangkan sendiri kebijakan-kebijakannya mengenai merek bagi mata produk dalam lini yang sama. Merek merupakan kombinasi dari nama, kata, simbol atau desain yang memberi identitas produk. Merek merupakan suatu tanda bagi konsumen untuk mengenal barang atau jasa yang di tawarkan. ${ }^{3}$

Dari perspektif konsumen, merek yang terpercaya merupakan jaminan atas konsistensi kinerja suatu produk dan menyediakan manfaat yang dicari konsumen ketika membeli produk atau merek tertentu. Merek juga merupakan janji kepada konsumen bahwa dengan hanya menyebut namanya, timbul harapan bahwa merek tersebut akan memberikan kualitas terbaik, kenyamanan, status dan pertimbangan lain ketika konsumen melakukan pembelian. ${ }^{4}$

Membicarakan konsep halal pada saat ini, merupakan hal yang sangat penting khususnya di Indonesia. ${ }^{5}$ Dalam kehidupan masyarakat Indonesia telah banyak mengenal dan menerapkan konsep halal. Alasan yang mendasarinya di karenakan penduduk Indonesia yang sebagian besar merupakan umat muslim. Menurut hasil sensus penduduk badan pusat statistik (BPS) pada tahun 2010, bahwa penduduk Indonesia yang memeluk agama Islam berjumlah 207.176.162

${ }^{1}$ Ujang Sumarwan, Perilaku Konsumen: Teori dan Penerapannya dalam Pemasaran (Bogor: Ghalia Indonesia, 2011), hlm. 1.

${ }^{2}$ Morissan, Periklanan: Komunikasi Pemasaran Terpadu (Jakarta: Kencana Prenada Media group, 2010), hlm.84.

${ }^{3}$ Kasmir, Kewirausahaan (Jakarta: PT. Raja Grafindo Persada, 2006), hlm. 174.

${ }^{4}$ M. Suyanto, Marketing Strategi Top Brand Indonesia (Yogyakarta: CV. Andi Offset, 2007), hlm. 77.

${ }^{5}$ Azhari Akmal Tarigan, dari Etika Ke Spritualitas Bisnis (Medan: IAIN Press , 2014), hlm. 64. 
atau sebesar 77,356\% (Data Terlampir) yang terdapat di 33 provinsi di Indonesia. ${ }^{6}$ Oleh sebab itu, perusahaan harus bisa memanfaatkan peluang untuk menciptakan produk-produk yang halal. Bagi umat muslim, halal merupakan hal-hal yang boleh dan dapat dilakukan karena bebas atau tidak terikat dengan ketentuan-ketentuan yang melarangnya, Produk halal merupakan produk yang memenuhi syarat kehalalan sesuai dengan syariat Islam yaitu: ${ }^{7}$

1. Tidak mengandung babi atau produk-produk yang berasal dari babi serta tidak menggunakan alkohol.

2. Daging yang digunakan berasal dari hewan halal yang disembelih menurut tata cara syariat Islam.

3. Semua bentuk minuman yang tidak beralkohol.

4. Semua tempat penyimpanan, tempat penjualan, pengolahan, dan tempat transportasi tidak digunakan untuk barang yang tidak halal, tempat tersebut harus terlebih dahulu dibersihkan dengan tata cara yang diatur menurut syariat Islam.

5. Brand image (citra merek) Wardah sebagai produk kosmetik yang harus dijaga dengan sebaik mungkin, karena perilaku konsumen sekarang ini sangat pemilih dalam membelanjakan uangnya. Hanya produk yang berkualitas dan memiliki brand image baik yang merupakan faktor penting yang akan menentukan keputusan konsumen. Oleh karena itu, apa yang menentukan pembeli puas atau tidak puas terhadap pembeliannya terletak antara harapan konsumen dan kinerja produk yang dirasakan. Jika produk jauh dibawah harapan konsumen, maka konsumen akan kecewa. Begitu juga sebaliknya, jika produk jauh di atas harapan konsumen, maka konsumen akan lebih senang.

Tabel 1.1 Topbrand award

\begin{tabular}{|l|r|l|}
\hline \multicolumn{3}{|c|}{ BEDAK MUKA PADAT } \\
\hline \multicolumn{1}{|c|}{ Merek } & TBI & TOP \\
\hline Wardah & $17.2 \%$ & Top \\
\hline Pixy & $15.6 \%$ & Top \\
\hline Sariayu & $9.0 \%$ & Top \\
\hline La Tulipe & $8.9 \%$ & \\
\hline Viva & $8.0 \%$ & \\
\hline Maybelline & $4.5 \%$ & \\
\hline Oriflame & $4.3 \%$ & \\
\hline
\end{tabular}

\begin{tabular}{|l|c|l|}
\hline \multicolumn{3}{|c|}{ BEDAK MUKA TABUR } \\
\hline \multicolumn{1}{|c|}{ Merek } & TBI & TOP \\
\hline Wardah & $13.8 \%$ & Top \\
\hline Viva & $12.3 \%$ & Top \\
\hline Sariayu & $10.4 \%$ & Top \\
\hline Marcks & $7.9 \%$ & \\
\hline La Tulipe & $7.1 \%$ & \\
\hline Pigeon & $5.2 \%$ & \\
\hline \multicolumn{3}{|l}{} \\
\hline
\end{tabular}

Sumber: www.topbrand award2015.com

Dari tabel di atas menunjukkan bahwa tahun 2015 produk merek wardah memiliki keunggulan atas kualitasnya, mempunyai brand image yang baik, serta memiliki kehalalan

${ }^{6}$ http://sp2010.bps.go.id/index.php/site/tabel?tid=321, di akses pada tanggal 15 Januari 2017, jam 14.22 Wib.

${ }^{7}$ Agus Sucipto, Studi Kelayakan Bisnis: Analisis Integratif dan Studi Kasus (Malang: UIN Maliki Press, 2010), hlm. 39-40. 
yang terdapat didalamnya, dan memiliki topbrand yang tinggi dibandingkan dengan produk-produk yang lain. Oleh sebab itu produk kosmetik merek wardah merupakan salah satu produk kosmetik yang cukup terkenal dan melekat di benak konsumen.

Produk Wardah merupakan pelopor pertama produk kosmetik yang mengutamakan kehalalan dalam pembuatan produknya dan memperoleh sertifikat halal dari Majelis Ulama Indonesia (MUI) serta memperoleh penghargaan "International Halal Award" dari World Halal Council pada tahun 2014 sebagai pelopor kosmetik halal di dunia. Penghargaan ini tentunya akan menaikkan atau meningkatkan brand image (citra merek) produk tersebut.

Adapun tujuan penelitian ini adalah: untuk mengetahui apakah Brand Image berpengaruh terhadap Keputusan Pembelian Kosmetik Wardah pada Mahasiswi Jurusan Ekonomi Syariah Fakultas Ekonomi dan Bisnis Islam IAIN Padangsidimpuan; untuk mengetahui apakah Label Halal berpengaruh terhadap Keputusan Pembelian Kosmetik Wardah pada Mahasiswi Jurusan Ekonomi Syariah Fakultas Ekonomi dan Bisnis Islam IAIN Padangsidimpuan; dan untuk mengetahui apakah Brand Image dan Label Halal berpengaruh secara simultan terhadap Keputusan Pembelian Kosmetik Wardah pada Mahasiswi

\section{KAJIAN TEORI}

Pemasaran sebenarnya merupakan aktivitas yang biasa dilakukan oleh setiap orang dalam hidupnya. Setiap organisasi, baik bisnis maupun nonbisnis, juga tidak terlepas dari aktivitas pemasaran. Memproduksi barang/jasa untuk memuaskan kebutuhan dan keinginan pelanggan, menyampaikan produk ke konsumen atau klien, merupakan beberapa contoh aktivitas pemasaran yang selalu dilakukan oleh organisasi. ${ }^{8}$

Menurut the American Marketing Association, pemasaran adalah sebagai proses perencanaan dan pelaksanaan rencana penetapan harga, promosi, dan distribusi dari ide-ide, barang-barang, dan jasa-jasa untuk menciptakan pertukaran yang memuaskan tujuan-tujuan individual dan organisasional. ${ }^{9}$

Pemasaran merupakan usaha terpadu untuk menggabungkan rencana-rencana strategis yang di arahkan kepada usaha pemuas kebutuhan dan keinginan konsumen untuk memperoleh keuntungan yang diharapkan melalui proses pertukaran atau transaksi. Sedangkan menurut Ujang Sumarwan pemasaran ialah suatu proses bagaimana mengidentifikasi kebutuhan konsumen kemudian memproduksi barang atau jasa yang dibutuhkan konsumen tersebut dan meyakinkan konsumen bahwa mereka membutuhkan barang atau jasa tersebut, sehingga terjadi transaksi atau pertukaran antara produsen dengan konsumen. ${ }^{10}$

Keputusan adalah seleksi terhadap dua pilihan alternatif atau lebih, Dengan kata lain pilihan alternatif harus tersedia bagi seseorang ketika mengambil keputusan. ${ }^{11}$ Jika seseorang mempunyai pilihan antara melakukan pembelian dan tidak melakukan pembelian, pilihan antara

\footnotetext{
${ }^{8}$ Pandji Anoraga, Manajemen Bisnis (Jakarta: Rineka Cipta, 2009), hlm. 214.

${ }^{9}$ Ibid., hlm. 215.

${ }^{10}$ Ujang Sumarwan, Op. Cit., hlm. 17.

${ }^{11}$ Leon Gschiffman dan leslie Lazar Kanuk, Perilaku Konsumen (Jakarta: PT. Indeks, 2004), hlm. 485.
} 
merek A dan merek B maka orang tersebut berada dalam posisi untuk mengambil keputusan sebaliknya, jika konsumen tersebut tidak mempunyai alternatif untuk memilih dan benar-benar terpaksa melakukan pembelian tertentu atau mengambil tindakan tertentu, maka keadaan satusatunya "tanpa pilihan lain" ini bukanlah suatu keputusan. Akan tetapi keputusan tersebut suatu keadaan tanpa pilihan biasanya disebut "pilihan hobson". Maka dapat disimpulkan bahwa pengambilan keputusan merupakan proses pemilihan alternatif terbaik dari beberapa alternatif secara sistematis untuk di tindaklanjuti (digunakan) sebagai suatu cara pemecahan masalah. ${ }^{12}$

a. Peran dalam Pembelian

Ada empat peran yang dimainkan orang dalam suatu keputusan pembelian yaitu: ${ }^{13}$

1) Pengambil inisiatif (initiator), yaitu seseorang yang pandangannya atau sarannya diperhitungkan dalam pengambilan keputusan.

2) Orang yang mempengaruhi (influencer), yaitu seseorang yang memutuskan sebagian besar keputusan membeli, seperti: apakah jadi membeli, apa yang dibeli, bagaimana membelinya, atau dimana membelinya.

3) Pembeli (buyer), yaitu seseorang yang melakukan pembelian yang sebenarnya.

4) Pemakai (user), yaitu seseorang yang mengkonsumsi atau menggunakan barang atau jasa yang dibeli.

b. Proses Keputusan Pembelian

Setiap hari konsumen mengambil berbagai keputusan untuk membeli produk dan jasa. Perusahaan, khususnya perusahaan besar, pada umumya melakukan riset dengan cermat tentang keputusan konsumen membeli produk untuk mengetahui sesuatu yang dibeli oleh konsumen, tempat, alasan, dan cara mereka membeli serta tingkat harga yang mereka bayar. Mengkaji alasan perilaku pembelian konsumen dan proses keputusan untuk membeli bukan hal yang mudah karena alasan tersebut berada di dalam pikiran konsumen.

Tahapan untuk mencapai keputusan membeli dilakukan oleh konsumen melalui beberapa tahapan, meliputi: ${ }^{14}$ mengenali kebutuhan, mencari informasi, evaluasi alternatif, keputusan membeli, dan perilaku setelah pembelian. Tahapan-tahapan tersebut dapat diilustrasikan dalam bagan gambar:

Gambar 2.1 Proses Keputusan Pembelian

Mengenali
Kebutuhan $\rightarrow \begin{gathered}\text { Mencari } \\ \text { Informasi }\end{gathered} \rightarrow \begin{gathered}\text { Evaluasi } \\ \text { Alternatif }\end{gathered} \rightarrow \begin{gathered}\text { Keputusan } \\ \text { Membeli }\end{gathered} \rightarrow \begin{gathered}\text { Perilaku Pasca } \\ \text { Pembelian }\end{gathered}$

Gambar di atas menunjukkan bahwa konsumen melalui lima tahapan setiap kali melakukan pembelian. Namun dalam praktik pembelian yang dilakukan secara rutin, tidak jarang konsumen mengabaikan atau melakukan tindakan yang berlawanan dengan beberapa tahapan tersebut. Seseorang yang membeli susu kesukaannya akan mengingat

\footnotetext{
${ }^{12}$ Nugroho J. Setiadi, Business Economics and Managerial Decision Making: Aplikasi Teori Ekonomi dan Pengambilan Keputusan Manajerial dalam Dunia Bisnis (Jakarta: Kencana, 2008), hlm. 17.

${ }^{13}$ Pandji Anoraga, Op. Cit., hlm. 229.

${ }^{14}$ Mahmud Machfoedz, Pengantar Bisnis Modern (Yogyakarta: CV. Andi Offset, 2007), hlm. 61-62.
} 
kebutuhan tersebut dan langsung mengambil keputusan untuk membeli dengan mengabaikan pencarian informasi dan evaluasi alternatif. Meskipun demikian, model dalam gambar tersebut tetap berlaku karena gambar ini menunjukkan semua pertimbangan yang terjadi ketika konsumen akan membeli produk baru dan berada dalam kondisi pembelian yang kompleks.

1) Pengenalan kebutuhan

Proses pembelian bermula dengan mengenali kebutuhan. Pembeli merasakan perbedaan diantara nyata dan kondisi yang diinginkan. Kebutuhan dapat dipicu oleh stimuli internal pada saat kebutuhan normal, seperti lapar, haus yang muncul hingga tingkat yang dapat menjadi pendorong. Kebutuhan juga dapat dipicu oleh stimuli eksternal. Iklan yang menawarkan suatu produk atau jasa dapat menjadikan seseorang menyadari kebutuhanya. Pada tahap ini produsen atau pemasar perlu menetapkan faktor dan keadaan yang dapat memicu konsumen mengenali kebutuhannya.

2) Mencari informasi

Konsumen di sadari atau tidak, akan mencari informasi. Jika motivasinya kuat dan produk yang sesuai dengan kebutuhan dan harganya terjangkau olehnya, mungkin ia akan membelinya. Jika tidak maka konsumen itu barangkali hanya akan mengingat kebutuhan tersebut atau mencari informasi sebatas yang berkaitan dengan kebutuhannya. Pencarian informasi mulai dilakukan ketika konsumen memandang bahwa kebutuhan tersebut bisa dipenuhi dengan membeli dan mengonsumsi suatu produk

Konsumen dapat memperoleh informasi yang tersimpan dalam ingatannya (pencarian internal) dan mencari informasi dari luar (pencarian eksternal) yang meliputi:

a) Individu: keluarga, kawan, tetangga, dan kerabat.

b) Komersial: iklan, wiraniaga, penyalur, kemasan, dan pameran.

c) Umum: media massa, lembaga konsumen.

d) Pengalaman: penggunaan produk, pemilikan produk, dan pengujian produk.

3) Evaluasi alternatif

Cara konsumen memproses informasi untuk sampai pada pemilihan merek disebut evaluasi altenatif. Untuk mengetahui proses tersebut bukan hal yang mudah karena konsumen menempuh berbagai cara untuk mengevaluasi setiap situasi pembelian.

Konsep dasar tertentu dapat membantu menerangkan setiap proses evaluasi konsumen. Pertama, diasumsikan bahwa setiap konsumen berusaha untuk memenuhi beberapa kebutuhan dan mencari manfaat tertentu yang dapat diperoleh dengan membeli produk atau jasa. Selanjutnya, konsumen memandang produk sebagai sekelompok ciri barang dengan berbagai kapasitas yang menawarkan manfaat untuk memenuhi kebutuhan. Kamera, misalnya ciri produk ini meliputi kualitas gambar yang baik, mudah digunakan, ukuran yang praktis, harga yang terjangkau, dan juga ciri-ciri 
lain. Konsumen akan menentukan alternatif dalam memilih ciri produk yang manfaatnya sesuai dengan kebutuhan.

Kedua, konsumen akan memperhatikan tingkat perbedaan pada setiap keunggulan sifat produk. Perbedaan dapat terletak diantara ciri produk dan keunggulannya. Ciri keunggulan berasal dari penilaian konsumen ketika mereka berfikir tentang ciri produk. Meskipun demikian hal tersebut bukan merupakan yang terpenting bagi konsumen. Beberapa ciri suatu produk dapat menonjol karena iklan yang di baca oleh konsumen menyebutkan berbagai keunggulan sehingga mampu menempatkannya pada peringkat teratas dalam pikiran konsumen. Diantara ciri-ciri suatu produk adakalanya ada yang terlupakan oleh konsumen, dan ketika ciri tersebut disebutkan maka akan mengingatkannya pada keunggulan. Produsen atau pemasar harus lebih memperhatikan arti penting ciri suatu produk dari pada keunggulannya.

Ketiga, konsumen mungkin akan mengembangkan ketepatan rasa percaya pada suatu merek dengan merinci setiap keunggulannya. Pengembangan kepercayaan pada merek tertentu ini kemudian dikenal sebagai brand image (citra merek). Kepercayaan konsumen dapat bervariasi dari kebenaran berdasarkan pengalaman.

4) Keputusan untuk membeli

Pada tahap evaluasi, konsumen menyusun peringkat merek dan membentuk tujuan pembelian. Biasanya keputusan pembelian konsumen akan menetapkan untuk membeli merek yang paling diminati. Jika memilih untuk membeli produk, dalam hal ini konsumen dihadapkan pada beberap alternatif pengambilan keputusan seperti produk, merek, penjual, kualitas, dan waktu pembeliannya.

5) Perilaku pasca pembelian

Secara umum, apabila seseorang merasakan ketertarikan yang sangat atau kepuasan dalam memenuhi kebutuhan, biasanya akan terus mengingat hal tersebut. Setelah melakukan pembelian, konsumen akan melakukan penilaian terhadap produk yang telah dipilihnya. Jika produk tersebut ternyata tidak dapat memuaskan harapannya, maka ia tidak akan membeli produk tersebut lagi. Sebaliknya, jika produk tersebut mampu memuaskan harapannya, maka ia akan membeli produk tersebut lagi kelak dan kemungkinan ia juga akan mengusulkan kepada rekan-rekannya untuk membeli produk tersebut. ${ }^{15}$

c. Tipe pengambilan keputusan konsumen

Ada empat tipe pengambilan keputusan konsumen, yaitu pengambilan keputusan yang kompleks, pengambilan keputusan terbatas, loyalitas terhadap merek, dan inertia. ${ }^{16}$

\footnotetext{
${ }^{15}$ Sunardi dan Anita Primastiwi, Op. Cit., hlm.183-184.

${ }^{16}$ Pandji Anoraga, Op. Cit., hlm.229.
} 
Tabel 2.1

Tipe pengambilan keputusan

\begin{tabular}{c|c|c|}
\cline { 2 - 3 } $\begin{array}{c}\text { Pengambilan } \\
\text { keputusan(mencari } \\
\text { informasi dan }\end{array}$ & Keterlibatan tinggi & Keterlibatan rendah \\
\cline { 2 - 3 } $\begin{array}{c}\text { mempertimbangkan } \\
\text { alternatif merek) }\end{array}$ & $\begin{array}{c}\text { Pengambilan } \\
\text { keputusan yang } \\
\text { terbatas }\end{array}$ & $\begin{array}{c}\text { Pengambilan } \\
\text { keputusan yang } \\
\text { kompleks }\end{array}$ \\
\hline $\begin{array}{c}\text { Habit (sedikit atau tanpa } \\
\text { pencarian informasi, } \\
\text { mempertimbangkan } \\
\text { hanya satu merek) }\end{array}$ & $\begin{array}{c}\text { Loyalitas terhadap } \\
\text { merek }\end{array}$ & Inertia \\
\hline
\end{tabular}

Tabel di atas menunjukkan bahwa keterlibatan pembelian yang tinggi diperlukan jika produk tersebut penting bagi konsumen, seperti jika pembelian tersebut terkait dengan ego atau citra diri konsumen. Disini ada satu resiko yang harus dihadapi konsumen, seperti resiko finansial, resiko sosial, atau psikologis. Dalam pengambilan keputusan ini diperlukan waktu dan energi yang banyak untuk mempertimbangkan alternatif produk.

\section{Faktor-Faktor yang memengaruhi keputusan pembelian konsumen}

Faktor yang memengaruhi perilaku konsumen terbagi dalam tiga kelompok, yaitu: ${ }^{17}$

a. Faktor Pribadi

Faktor pribadi merupakan faktor yang unik bagi seseorang. Berbagai faktor pribadi dapat memengaruhi keputusan pembelian. Faktor pribadi digolongkan menjadi tiga, yaitu:

1) Faktor Demokrafi

Faktor demokrafi berkaitan dengan siapa yang terlibat dalam pengambilan keputusan pembelian. Faktor inii meliputi ciri-ciri individual seperti jenis kelamin, usia, ras, suku bangsa, pendapatan, siklus, kehidupan keluarga, dan pekerjaan.

2) Faktor Situasional

Faktor situasional merupakan keadaan atau kondisi eksternal yang ada ketika konsumen membuat keputusan pembelian.

3) Faktor Tingkat Keterlibatan

Faktor tingkat keterlibatan konsumen ditunjukkan dengan sejauh mana konsumen mempertimbangkan terlebih dahulu keputusannya sebelum membeli suatu produk.

\section{b. Faktor Psikologis}

Faktor psikologis yang ada pada diri seseorang sebagian menetapkan perilaku orang tersebut sehingga memengaruhi perilakunya sebagai konsumen. Faktor-faktor psikologis meliputi:

\footnotetext{
${ }^{17}$ Etta Mamang Sangadji dan Sopiah, Op. Cit., hlm. 335-337.
} 
1) Motif

Motif adalah kekuatan energi internal yang mengarahkan kegiatan seseorang ke arah pemenuhan kebutuhan atau pencapaian sasaran.

2) Persepsi

Persepsi adalah proses pemilihan, pengorganisasian, dan penginterpretasian masukan informasi untuk menghasilkan makna.

3) Kemampuan dan Pengetahuan

Kemampuan adalah kesanggupan dan efisiensi untuk melakukan tugas-tugas tertentu. Kemampuan yang diminati oleh para pemasar adalah kemampuan seorang individu untuk belajar dimana proses pembelajaran tersebut merupakan perubahan perilaku seseorang yang disebabkan oleh informasi dan pengalaman.

4) Sikap

Sikap merujuk pada pengetahuan dan persaan positif atau negatif terhadap sebuah objek atau kegiatan tertentu.

5) Kepribadian

Kepribadian adalah semua ciri internal dan perilaku yang membuat seeorang itu unik. Kepribadian seseorang berasal dari keturunan dan pengalaman pribadi.

Keterkaitan antara brand image dengan keputusan pembelian terletak dalam faktor psikologis yaitu dari segi persepsi dan sikap, dimana persepsi dan sikap merupakan bagian dari indikator brand image untuk mengukur pernyataan-pernyataan konsumen terhadap suatu produk.

c. Faktor Sosial

Manusia hidup di tengah-tengah masyarakat. Sudah tentu manusia akan dipengaruhi oleh masyarakat dimana dia hidup. Dengan demikian, perilaku konsumen juga akan dipengaruhi oleh masyarakat atau faktor sosial yang melingkarinya. Faktor sosial tersebut meliputi:

1) peran dan Pengaruh Keluarga

Dalam kaitannya dengan perilaku konsumen, keluarga mempunyai pengaruh langsung terhadap keputusan pembelian konsumen. Setiap anggota keluarga mempunyai kebutuhan, keinginan, dan selera yang berbeda-beda.

2) Kelompok Referensi

Kelompok referensi dapat berfungsi sebagai perbandingan dan sumber informasi bagi seseorang sehingga perilaku para anggota kelompok referensi ketika membeli suatu produk bermerek tertentu akan dapat dipengaruhi oleh kelompok referensi.

3) Kelas Sosial

Kelas sosial adalah sebuah kelompok yang terbuka untuk para individu yang memiliki tingkat sosial yang serupa. Dalam kelas sosial terjadi pembedaan masyarakat ke dalam kelas-kelas secara bertingkat, ada kelas yang tinggi, ada kelas yang rendah.

4) Budaya dan Subbudaya 
Budaya memengaruh bagaimana seseorang membeli dan menggunakan produk, serta kepuasan konsumen terhadap produk tersebut sebab budaya juga menentukan produk-produk yang dibeli dan digunakan. Setiap budaya memiliki subbudaya yang lebih kecil atau kelompok orang yang merasa menjadi bagian suatu sistem nilai atas dasar kesamaan pengalaman dan keadaan hidup bersama. Subbudaya mencakup kelompok nasionalitas, keagamaan, kesukuan, dan kewilayahan. Banyak subbudaya merupakan segmen pemasaran penting dan pemasar sering membuat rancangan produk khusus disesuaikan keinginan segmen. Bagi pemasar di Indonesia, dimana mayoritas penduduknya beragama Islam mengharuskan mereka untuk mendapatkan sertifikasi halal untuk setiap produk yang berhubungan dengan makanan, obat-obatan, dan kosmetik. Konsumen yang beragama Islam lebih cendrung memerhatikan kehalalan suatu produk, sebelum dia membeli produk tersebut. ${ }^{18}$

Keterkaitan keputusan konsumen dengan label halal terletak pada faktor sosial dari segi subbudaya, dimana dalam subbudaya ini dijelaskan bahwa di Indonesia diharuskan untuk memproduksi produk yang halal dan mendapatkan sertifikat halal sebagai jaminan suatu produk baik makanan, obat-obatan, dan kosmetik.

\section{Brand Image (citra merek)}

a. Image (Citra)

Image (Citra) adalah tujuan utama, dan sekaligus merupakan reputasi dan prestasi yang hendak dicapai bagi perusahaan dan hubungan masyarakat atau public relations. Pengertian image (citra) itu sendiri abstrak dan tidak dapat diukur secara matematis, tetapi wujudnya bisa dirasakan dari hasil penilaian baik atau buruk, Seperti penerimaan dan tanggapan baik positif maupun negatif yang khususnya datang dari masyarakat luas pada umumnya. ${ }^{19}$

Penilaian atau tanggapan masyarakat tersebut dapat berkaitan dengan timbulnya rasa hormat (respek), kesan-kesan yang baik dan menguntungkan terhadap suatu image (citra) lembaga/organisasi atau produk barang dan jasa pelayanannya yang diwakili oleh humas. Biasanya landasan image (citra) itu berakar dari "nilai-nilai kepercayaan" yang terdapat pada produknya yang kongkretnya diberikan secara individual, dan merupakan pandangan atau persepsi. Proses akumulasi dari amanah kepercayaan yang telah diberikan oleh individu-individu tersebut akan mengalami suatu proses cepat atau lambat untuk membentuk suatu opini public yang lebih luas, yaitu sering dinamakan image (citra).

b. Brand (Merek)

Brand (Merek) adalah suatu nama, istilah, tanda, simbol, desain atau kombinasi untuk menandai produk atau dari satu penjual atau kelompok penjual untuk membedakan dari produk pesaingnya. ${ }^{20}$ Memilih satu merek bagi suatu produk merupakan kegiatan

\footnotetext{
${ }^{18}$ Nugroho J Setiadi, Prilaku Konsumen: Perspektif Kontemporer pada Motif, Tujuan, dan Keinginan Konsumen (Jakarta: kencana, 2003), hlm. 293.

${ }^{19}$ Rosady Ruslan, Manajemen Public Relations dan Media Komunikasi: Konsepsi dan Aplikasi (Jakarta: Raja Grafindo Persada, 2005), hlm. 74-78.

${ }^{20}$ Nembah F. Hartimbul Ginting, Manajemen Pemasaran (Bandung: CV. Yrama Widya, 2011), hlm. 99.
} 
yang penting ditinjau dari perspektif promosi karena nama merek berfungsi menyampaikan atribut dan makna. ${ }^{21} \mathrm{Jadi}$, brand (merek) menandai pembuat atau penjual suatu produk. Defenisi serupa juga ditemukan dalam pasal 1 undang-undang No. 15 tahun 2001 tentang merek: tanda yang berupa gambar, nama, kata, huruf-huruf, angka-angka, susunan warna, atau kombinasi dari unsur-unsur tersebut yang memiliki daya pembeda dan digunakan dalam kegiatan perdagangan barang atau jasa. ${ }^{22}$

Dalam menentukan merek suatu produk, praktisi pemasaran harus memilih nama yang dapat menginformasikan konsep produk dan dapat membantu menempatkan atau memosisikan produk di memori atau diingatan konsumen. ${ }^{23}$ Suatu merek harus dapat menyampaikan manfaat yang diperoleh dengan menggunakan produk yang bersangkutan dan pada saat yang sama juga menciptakan image (citra) bagi produk itu.

Kerangka pikir yang dapat peneliti gambarkan sebagai berikut:

\section{Gambar 2.2 Kerangka Pikir}

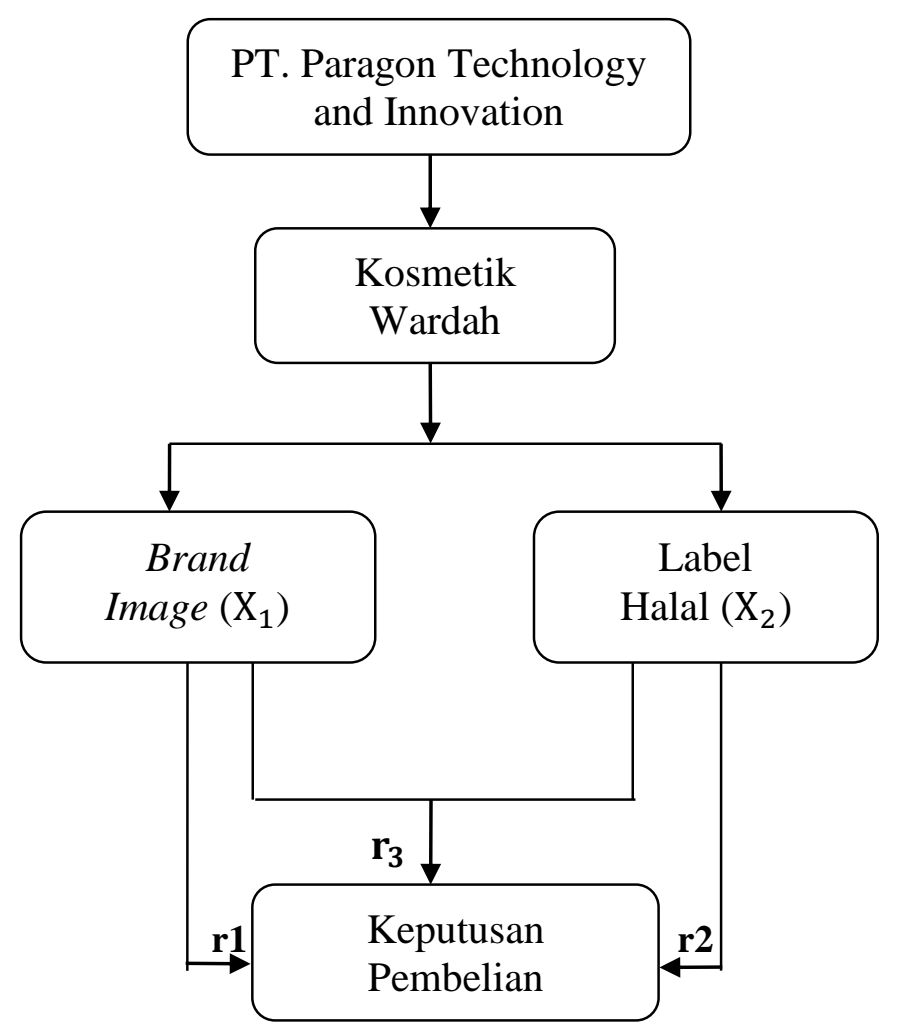

\footnotetext{
${ }^{21}$ Morissan, Op. Cit., hlm. 76.

${ }^{22}$ Casavera, 15 Kasus Sengketa Merek Di Indonesia (Yogyakarta: Graha Ilmu, 2009), hlm. 3.

${ }^{23}$ Morissan, Log. Cit., hlm. 76.
} 


\section{METODE PENELITIAN}

1. Lokasi dan waktu Penelitian

Penelitian ini dilaksanakan di IAIN Padangsidimpuan khususnya Mahasiswi Jurusan Ekonomi Syariah Fakultas Ekonomi dan Bisnis Islam (FEBI). Waktu penelitian ini dilaksanakan pada bulan November 2016 sampai dengan 31 Maret 2017.

2. Jenis penelitian

Penelitian ini merupakan jenis penelitian kuantitatif. Yang mana penelitian kuantitatif adalah menggunakan data berupa angka untuk dikelola atau yang bekerja dengan angka, yang datanya berwujud bilangan (nilai atau skor, peringkat atau frekuensi), yang dianalisis dengan menggunakan statistik untuk menjawab pertanyaan-pertanyaan.

3. Populasi dan sampel

a. Populasi

Populasi dalam penelitian merupakan keseluruhan dari obyek yang dapat berupa manusia, obyek, transaksi, atau kejadian dimana kita tertarik untuk mempelajarinya atau menjadi objek penelitian, sehingga obyek-obyek ini dapat menjadi sumber penelitian. ${ }^{24}$ Dalam penelitian ini populasi yang diambil merupakan seluruh Mahasiswi Jurusan Ekonomi Syariah Fakultas Ekonomi dan Bisnis Islam IAIN padangsidimpuan. Jumlah seluruh mahasiswi jurusan ekonomi syariah sebagai berikut:

\begin{tabular}{|c|c|c|}
\hline No. & Tahun Angkatan/Semester & Jumlah Mahasiswi \\
\hline 1. & Tahun 2012/Semester X & 53 \\
\hline 2. & Tahun 2013/Semester VIII & 180 \\
\hline 3. & Tahun 2014/Semester VI & 170 \\
\hline 4. & Tahun 2015/Semester IV & 210 \\
\hline 5. & Tahun 2016/Semester II & 788 Mahasiswi \\
\hline & Jumlah & \\
\hline
\end{tabular}

Sumber: Kasubbag Akademik, Mahasiswa dan Alumni

b. Sampel

Sampel adalah bagian kecil dari populasi yang diambil menurut prosedur tertentu sehingga dapat mewakili populasinya. ${ }^{25}$ Sampel merupakan suatu bagian dari populasi yang akan diteliti dan yang dianggap dapat menggambarkan populasinya. Proses pemilihan sampel dari populasi dengan tujuan mendapatkan kesimpulan umum mengenai

${ }^{24}$ Mudrajad kuncoro, Metode Riset Untuk Bisnis dan Ekonomi (Jakarta: Erlangga, 2013), hlm. 118.

${ }^{25}$ Maman Abdurrahman dan Sambas Ali Muhidin, Panduan Praktik Memahami Penelitian (Bandung: CV. Pustaka Setia, 2011), hlm. 119. 
populasi berdasarkan hasil penelitian terdapat sampel yang dipilih. Dalam menentukan ukuran sampelnya maka peneliti menggunakan rumus slovin sebagai berikut: ${ }^{26}$

$$
\begin{aligned}
& \text { dimana: } \mathrm{n}=\text { jumlah sampel } \\
& \mathrm{N}=\frac{\mathrm{N}}{1+\mathrm{N}^{2}} \\
& \mathrm{e}=\text { jumlah populasi } \\
& \text { persen kelonggaran ketidaktelitian/batas kesalahan. }
\end{aligned}
$$

Sehingga jumlah sampel yang diperoleh dengan ketentuan yang digunakan $\mathrm{e}=10 \%$ adalah:

$$
\begin{aligned}
\mathrm{n} & =\frac{788}{1+788(0,01)} \\
& =\frac{788}{8,88} \\
& =88,73=89 \text { Responden }
\end{aligned}
$$

Teknik pengambilan sampel yang digunakan ialah Purposive Sampling. Purposive Sampling adalah teknik penentuan sampel dengan pertimbangan khusus sehingga layak dijadikan sampel. ${ }^{27}$ Pada umumnya, peneliti menggunakan metode ini karena kriteria yang digunakan oleh peneliti adalah mahasiswi yang menggunakan produk kosmetik wardah.

\section{Instrumen pengumpulan data}

Instrumen pengumpulan data adalah alat bantu yang di pilih dan di gunakan oleh peneliti dalam kegiatannya mengumpulkan, agar kegiatan tersebut menjadi sistematis dan dipermudah olehnya. ${ }^{28}$ Instrumen pengumpulan data yang digunakan peneliti dalam penelitian ini adalah menggunakan angket. Angket atau kuesioner merupakan sejumlah pertanyaan tertulis yang digunakan untuk memperoleh informasi dari responden dalam arti laporan tentang pribadinya atau hal-hal yang ia ketahui untuk dijawab. ${ }^{29}$ Untuk skala pengukuran data yang digunakan dalam penelitian ini yaitu skala likert. Skala likert merupakan skala yang popular di kalangan peneliti, karena penerapannya mudah dan sederhana dalam penafsiran.

\section{Sumber Data}

a. Data Primer

Data primer merupakan sumber data penelitian yang diperoleh secara langsung dari sumber asli (tidak melalui media perantara). Karena data primer dikumpulkan oleh peneliti, maka diperlukan sumber daya yang cukup memadai, seperti biaya, waktu,

\footnotetext{
${ }^{26}$ Rosady Ruslan, Metode Penelitian: Public Relations dan Komunikasi (Jakarta: Raja Grafindo Persada, 2004), hlm. 150.

${ }^{27} J u l i a n s y a h$ Noor, Metodologi Penelitian: Skripsi, Tesis, Disertasi, dan Karya Ilmiah (Jakarta: Kencana Prenada Media Group, 2011), hlm. 155.

${ }^{28}$ Suharsimi Arikunto, Manajemen Penelitian (Jakarta: PT. Rineka Cipta, 2007), hlm. 101.

${ }^{29}$ Suharsimi Arikunto, Prosedur Penelitian: Suatu Pendekatan Praktik (Jakarta: Rineka Cipta, 2013), hlm.
} 194. 
tenaga, dan sebagainya. ${ }^{30}$ Salah satu data primer yaitu angket, yang mana angket ini akan menjadi bahan bagi peneliti dalam mengumpulkan informasi dari responden. Skala pengukuran angket yang digunakan dalam penelitian ini yaitu skala likert yang mana mencakup tentang keputusan pembelian, brand image dan label halal.

b. Data Sekunder

Data sekunder adalah data yang telah dikumpulkan oleh pihak lain. ${ }^{31}$ Data sekunder biasanya telah dikumpulkan oleh lembaga pengumpul data dan dipublikasikan kepada masyarakat seperti sejarah dari Kampus IAIN Padangsidimpuan, visi misi IAIN Padangsidimpusn, serta data yang diambil dari jumlah keseluruhan mahasiswi jurusan ekonomi syariah fakultas ekonomi dan bisnis islam IAIN Padangsidimpuan.

6. Uji validitas dan Uji Reliabilitas Instrumen

a. Uji Validitas

Uji validitas merupakan uji instrumen data untuk mengetahui seberapa cermat suatu item dalam mengukur apa yang ingin diukur. Item dapat dikatakan valid jika adanya korelasi yang signifikan dengan skor totalnya, hal ini menunjukkan adanya dukungan item tersebut dalam mengungkap suatu yang ingin diungkap. Item biasanya berupa pertanyaan atau pernyataan yang ditujukan kepada responden dengan menggunakan bentuk koesioner dengan tujuan untuk mengungkap sesuatu. ${ }^{32}$

Adapun teknik korelasi yang biasa dipakai adalah teknik korelasi product moment dan untuk mengetahui apakah nilai korelasi tiap-tiap pertanyaan itu signifikan, maka dapat dilihat pada tabel nilai product moment atau menggunakan SPSS 22 untuk mengujinya. Untuk butir pertanyaan/pernyataan yang tidak valid harus dibuang atau tidak dipakai sebagai instrumen pertanyaan/pernyataan. ${ }^{33}$ Adapun dasar pengambilan keputusan yaitu:

1) Jika $r_{\text {hitung }}$ positif, serta $r_{\text {hitung }} \geq r_{\text {tabel }}$, maka butir atau item pertanyaan tersebut valid.

2) Jika $r_{\text {hitung }}$ positif serta $r_{\text {hitung }}<r_{\text {tabel }}$ maka butir atau item pertanyaan tersebut tidak valid. $^{34}$

b. Uji Reliabilitas

Uji reliabilitas digunakan untuk mengetahui konsistensi alat ukur yang biasanya menggunakan koesioner. Maksudnya apakah alat ukur tersebut akan mendapatkan pengukuran yang tetap konsisten jika pengukuran diulang kembali. Metode yang sering digunakan dalam penelitian untuk mengukur skala likert adalah Cronbach Alpha. Untuk menentukan apakah instrumen reliabel atau tidak menggunakan program SPSS 22, dalam

\footnotetext{
${ }^{30}$ Nur Asnawi dan Masyhuri, Metodologi Riset Manajemen Pemasaran: Disertai Dengan Contoh Hasil Penelitian (Malang: UIN-Maliki Press, 2011), hlm. 153-154.

${ }^{31}$ Mudrajad Kuncoro, Op. Cit., hlm. 148.

${ }^{32}$ Duwi priyatno, SPSS 22 Pengolahan Data Terpraktis (Yogyakarta: CV. Andi Offset, 2014), hlm. 51.

${ }^{33}$ Juliansyah Noor, Op. Cit., hlm. 132.

${ }^{34}$ Duwi Priyatno, Op.Cit., hlm. 55.
} 
pengujian reliabilitas digunakan dengan metode cronbach's alpha yang dimana satu kuesioner dianggap reliabel apabila cronbach's alpha $>0,600 .{ }^{35}$

\section{Analisis Data}

a. Statistik Deskriptif

Statistik deskriptif adalah statistik yang digunakan untuk menganalisis data dengan cara mendeskripsikan atau menggambarkan data yang telah terkumpul sebagaimana adanya tanpa bermaksud membuat kesimpulan yang berlaku untuk umum atau generalisasi. ${ }^{36}$ Analisis deskriptif digunakan untuk penggambaran tentang statistik data seperti mean, max, min, dan lain sebagainya. ${ }^{37}$ Mean (rata-rata) merupakan alat pengukuran rata-rata yang paling popular untuk mengetahui karakteristik dari sekelompok data. ${ }^{38}$ Keuntungan dari menghitung mean (rata-rata) adalah angka tersebut dapat digunakan sebagai gambaran atau wakil dari data yang diamati. Sedangkan maximum ialah nilai tertinggi dan minimum adalah nilai terendah.

b. Asumsi Dasar (Uji Prasyarat)

\section{1) Uji Normalitas}

Uji normalitas adalah pengujian dalam sebuah model regresi, variabel dependen, variabel indepenpen atau keduanya mempunyai distribusi normal atau tidak. Uji normalitas dimasukkan untuk mengetahui apakah residual yang diteliti berdistribusi normal atau tidak. Metode yang digunakan untuk menguji normalitas adalah dengan menggunakan Uji Kolmogorov-Smirnov. Pengambilan keputusan dari Uji Normalitas yang menggunakan metode Uji Kolmogorov-Smirnov maka kriteria pengujiannya sebagai berikut:

a) Jika nilai signifikan $<0,10$, maka $\mathrm{H} 0$ ditolak.

b) Jika nilai signifikansi $>0,10$, maka $\mathrm{H} 0$ diterima $^{39}$

\section{2) Uji Linearitas}

Uji linearitas digunakan untuk mengetahui linearitas data, yaitu apakah dua variabel mempunyai hubungan yang linear atau tidak. Uji ini digunakan sebagai prasyarat dalam analisis korelasi pearson atau regresi linear. Pengujian pada SPSS dengan menggunakan test for linearity pada taraf signifikansi 0,10. Dua variabel dikatakan mempunyai hubungan yang linear bila nilai signifikansi kurang dari 0,10.

a) Jika nilai signifikansi $<0,10$, maka kedua variabel mempunyai hubungan yang linear.

b) Jika nilai signifikansi > 0,10, maka kedua variabel tidak mempunyai hubungan yamg linear.

c. Asumsi Klasik

${ }^{35}$ Ibid., hlm. 54.

${ }^{36}$ Sugiyono, Metode Penelitian Kuantitatif, Kualitatif dan R\&D (Bandung: Alfabeta, 2009), hlm. 147.

${ }^{37}$ Duwi Priyatno, Op. Cit., hlm. 30.

${ }^{38}$ Singgih Santoso, Statistik Deskriptif: Konsep dan Aplikasi Dengan Microsoft Excel Dan SPSS (Yogyakarta: Andi, 2003), hlm. 99.

${ }^{39}$ Duwi Priyatno, Op.Cit., hlm. 78. 
Dalam pengujian hipotesis berdasarkan analisis regresi yang digunakan dalam penelitian ini harus memenuhi asumsi klasik. Untuk mendapatkan nilai pemeriksa yang tidak bias dan efisien dari suatu persamaan regresi linear berganda dengan metode kuadrat terkecil. Perlu dilakukan pengujian dengan memenuhi persyaratan asumsi klasik yang meliputi: ${ }^{40}$

1) Uji Multikolinearitas

Uji multikolinearitas bertujuan untuk menguji apakah pada model ditemukan adanya korelasi antara variabel independen. Jika terjadi korelasi maka terdapat problem multikolinearitas. Model regresi yang baik seharusnya tidak terjadi korelasi di antara variabel independen. Untuk mendeteksi adanya multikolinearitas dapat dilihat dari nilai tolerance dan VIF (Variance Inflaction Factor). Kriteria pengambilan keputusan dalam multikolinearitas ialah sebagai berikut:

Apabila nilai VIF (variance inflaction factor) kurang dari 10 dan nilai tolerance lebih dari 0,1 , maka dinyatakan tidak terjadi multikolinearitas. ${ }^{41}$

2) Uji Heteroskedastisitas

Heteroskedastisitas muncul apabila kesalahan atau residual dari model yang diamati tidak memiliki varians yang konstan dari satu variabel ke variabel lain, artinya setiap variabel mempunyai reliabilitas yang berbeda akibat perubahan dalam kondisi yang melatar belakangi tidak terangkum dalam spesifikasi model. Heteroskedastisitas diuji dengan menggunakan Uji Koefisien Korelasi Spearman's rho yaitu mengkorelasikan variabel independen dengan residualnya. Kriteria pengambilan keputusan heteroskedastisitas ialah sebagai berikut:

a) Jika korelasi antara variabel independen dengan residual didapat nilai signifikansi $<0,10$, maka dapat dikatakan bahwa terjadi problem heteroskedastisitas.

b) Jika korelasi antara variabel independen dengan residual didapat nilai signifikansi $>0,10$, maka dapat dikatan bahwa tidak terjadi problem heteroskedastisitas.

3) Uji Autokorelasi

Uji autokorelasi bertujuan untuk menguji apakah dalam sebuah model regresi linear berganda ada korelasi antara kesalahan pengganggu pada variabel satu dengan kesalahan pada variabel lain. Jika terjadi korelasi, maka terjadi autokorelasi. Model regresi yang baik adalah bebas dari autokorelasi.

Uji autokorelasi hanya dilakukan untuk data time series (runtun waktu) yang kemungkinan adanya autokorelasi antara nilai-nilai variabel yang berurutan lebih besar daripada penelitian yang menggunakan data cross section (seksi silang). ${ }^{42}$ Serta tidak perlu dilakukan pada data cross section seperti angket dimana pengukuran

\footnotetext{
${ }^{40}$ Nur Asnawi dan Masyhuri, Op. Cit., hlm. 176-179.

${ }^{41}$ Ibid., hlm. 103.

${ }^{42}$ Muhammad Firdaus, Ekonometrika Suatu Pendekatan Aplikatif (Jakarta: PT. Bumi Aksara, 2004), hlm. 99.
} 
semua variabel dilakukan secara bersama-sama. Jadi peneliti dapat menyimpulkan bahwa pada penelitian ini tidak menggunakan uji autokorelasi.

d. Analisi Regresi Linear Berganda

Analisis regresi linear berganda mempunyai langkah yang hampir sama dengan analisis regresi linear sederhana. Yang menjadi pembeda antara kedua terletak pada variabel yang dimiliki peneliti. Analisis regresi adalah kelanjutan setelah uji validitas, realibilitas, dan uji asumsi klasik. Analisis regresi linear berganda merupakan persamaan regresi dengan menggunakan dua atau lebih variabel independen. Bentuk persamaan regresi linear berganda ini adalah: ${ }^{43}$

$$
Y=a+b_{1} X_{1}+b_{2} X_{2}+e
$$

\section{Keterangan:}

$\mathrm{Y}=$ keputusan Pembelian

$\mathrm{b}=$ Konstanta perubahan variabel $\mathrm{X}$ terhadap $\mathrm{Y}$

$\mathrm{a}=$ Koefisien Konstanta

$\mathrm{X}_{1}=$ Brand Image

$\mathrm{X}_{2}=$ Label Halal

$\mathrm{e}=$ error (tingkat kesalahan)

Sehingga rumus dalam penelitian ini adalah $\mathrm{KP}=\mathrm{a}+\mathrm{b}_{1} \mathrm{BI}+\mathrm{b}_{2} \mathrm{LH}+\mathrm{e}$

e. Uji Hipotesis

1) Koefisien Determinasi $\left(R^{2}\right)$,

Koefisien determinasi $\left(\mathrm{R}^{2}\right)$ digunakan untuk mengetahui sampai sejauh mana ketepatan atau kecocokan garis regresi yang terbentuk dalam mewakili kelompok data. Koefisien determinasi $\left(\mathrm{R}^{2}\right)$ menggambarkan bagian dari variasi total yang dapat diterangkan oleh model. Dalam penelitian ini peneliti menggunakan tiga variabel yaitu regresi $Y$ terhadap $X_{1}$ dan $X_{2}$, hal ini ingin diketahui bahwa seberapa besarnya persentase sumbangan $X_{1}$ dan $X_{2}$ terhadap variasi (naik turunnya) $Y$ secara bersamasama. Besarnya persentase sumbangan ini disebut koefisien determinasi berganda dengan simbol $\mathrm{R}^{2} \cdot{ }^{44}$

Pengambilan keputusan koefisien determinasi yaitu: apabila Semakin besar nilai $\mathrm{R}^{2}$ (mendekati 1), maka ketepatannya dikatakan semakin baik. Apabila nilai $0 \leq \mathrm{R}^{2} \leq$ dapat diartikan sebagai berikut:

a) $\mathrm{R}^{2}=0$, berarti tidak ada hubungan antara $\mathrm{X}$ dan $\mathrm{Y}$, atau model regresi yang terbentuk tidak tepat untuk meramalkan Y.

b) $\mathrm{R}^{2}=1$, berarti ada hubungan antara $\mathrm{X}$ dan $\mathrm{Y}$, atau model regresi yang terbentuk dapat meramalkan Y secara sempurna. ${ }^{45}$

\footnotetext{
${ }^{43}$ Duwi Priyatno, Op. Cit., hlm. 160.

${ }^{44}$ Muhammad Firdaus, Op. Cit., hlm. 77.

${ }^{45}$ Setiawan dan Dwi Endah Kusrini, Ekonometrika (Yogyakarta: CV. Andi Offset, 2010), hlm. 64.
} 
Tabel 3.5

\section{Pedoman untuk memberikan interprestasi}

Koefisien korelasi ${ }^{46}$

\begin{tabular}{|c|c|}
\hline Interval koefisien & Tingkat hubungan \\
\hline $0,00-0,199$ & Sangat rendah \\
\hline $0,20-0,399$ & Rendah \\
\hline $0,40-0,599$ & Sedang \\
\hline $0,60-0,799$ & Kuat \\
\hline $0,80-1,000$ & Sangat kuat \\
\hline
\end{tabular}

2) Uji Parsial (Uji t)

Uji statistik ini digunakan untuk membuktikan signifikan atau tidaknya pengaruh variabel bebas terhadap variabel tak bebas. Maka nilai signifikansi yang digunakan adalah 0,10. Muhammad Firdaus memberikan penjelasan pada dasar pengambilan keputusan pengujian hipotesis secara parsial ( $t$ test) yaitu:

a) Jika $t_{\text {hitung }}<-\mathrm{t}_{\text {tabel }}$ atau $\mathrm{t}_{\text {hitung }}>+\mathrm{t}_{\text {tabel }}$ maka $\mathrm{H}_{0}$ ditolak dan $\mathrm{H}_{\mathrm{a}}$ diterima.

b) Jika $\mathrm{t}_{\text {tabel }} \leq \mathrm{t}_{\text {hitung }} \leq \mathrm{t}_{\text {tabel }}$ maka $\mathrm{H}_{0}$ diterima dan $\mathrm{H}_{\mathrm{a}}$ ditolak. ${ }^{47}$

Dengan merumuskan hipotesis sebagai berikut:

H01 = Tidak terdapat pengaruh yang signifikan antara brand image terhadap keputusan pembelian kosmetik wardah secara parsial.

Hal $=$ Terdapat pengaruh yang signifikan antara brand image terhadap keputusan pembelian kosmetik wardah secara parsial.

H02 = Tidak terdapat pengaruh yang signifikan antara label halal terhadap keputusan pembelian kosmetik wardah secara parsial.

$\mathrm{Ha} 2=$ Terdapat pengaruh yang signifikan antara label halal terhadap keputusan pembelian kosmetik wardah secara parsial.

3) Uji Simultan (Uji F)

Uji simultan F pada dasarnya menunjukkan apakah semua variabel bebas yang dimasukkan dalam model mempunyai pengaruh secara bersama-sama terhadap

\footnotetext{
${ }^{46}$ Sugiyono, Op. Cit., hlm. 250.

${ }^{47}$ Muhammad Firdaus, Op. Cit., hlm. 88.
} 
variabel terikat. ${ }^{48}$ Muhammad Firdaus mengemukakan bahwa keputusan yang diambil dalam pengujian hipotesis secara simultan yaitu:

a) Jika $\mathrm{F}_{\text {hitung }}>\mathrm{F}_{\text {tabel }}$ maka $\mathrm{H}_{0}$ ditolak dan $\mathrm{H}_{\mathrm{a}}$ diterima, sebaliknya

b) Jika $\mathrm{F}_{\text {hitung }}<\mathrm{F}_{\text {tabel }} \mathrm{H}_{0}$ diterima dan $\mathrm{H}_{\mathrm{a}}$ ditolak. ${ }^{49}$

Dengan merumuskan hipotesis sebagai berikut:

$\mathrm{H} 0=$ Tidak terdapat pengaruh brand image dan label halal secara simultan terhadap keputusan pembelian kosmetik wardah pada mahasiswi jurusan ekonomi syariah fakultas ekonomi dan bisnis Islam IAIN padangsidimpan.

$\mathrm{Ha}=$ Terdapat pengaruh brand image dan label halal secara simultan terhadap keputusan pembelian kosmetik wardah pada mahasiswi jurusan ekonomi syariah fakultas ekonomi dan bisnis Islam IAIN padangsidimpuan.

\section{HASIL PENELITIAN DAN PEMBAHASAN}

1. Uji Validitas

Uji validitas bertujuan untuk mengetahui kesahihan sejauh mana suatu alat ukur mampu mengukur yang diukur. Setelah angket disebarkan ke responden maka akan diperoleh hasil. Sebelum dianalisis angket terlebih dahulu di uji validitas. Hal ini digunakan untuk melihat kesahihan dari sebuah item pernyataan. Uji validitas yang digunakan untuk menguji 6 butir pernyataan untuk brand image, 8 butir pernyataan untuk label halal, dan 10 butir pernyataan untuk keputusan pembelian. Hasil dari uji validitas brand image sebagai berikut:

Tabel IV.1

Hasil Uji Validitas Variabel Brand Image

\begin{tabular}{|c|c|c|c|}
\hline No & $\mathrm{r}_{\text {hitung }}$ & $r_{\text {tabel }}$ & Keterangan \\
\hline 1 & 0,640 & \multirow{6}{*}{$\begin{array}{l}\text { Instrumen valid jika }>r_{\text {tabel }} \\
\text { dengan } n=89 \text { pada taraf } \\
\text { signifikan } 10 \% \text { sehingga } \\
\text { diperoleh } r_{\text {tabel }} 0,1735\end{array}$} & Valid \\
\hline 2 & 0,668 & & Valid \\
\hline 3 & 0,695 & & Valid \\
\hline 4 & 0,504 & & Valid \\
\hline 5 & 0,758 & & Valid \\
\hline 6 & 0,634 & & Valid \\
\hline
\end{tabular}

Sumber: Data diolah dari hasil output SPSS 22

Dari hasil uji validitas brand image di atas pada tabel IV.1 dapat diketahui bahwa $r_{\text {hitung }}$ seluruh item pernyataan $>r_{\text {tabel }}$ Maka dapat disimpulkan bahwa seluruh item pernyataan

\footnotetext{
${ }^{48}$ Mudrajat Kuncoro, Op. Cit., hlm. 245.

${ }^{49}$ Muhammad Firdaus, Op. Cit., hlm. 89.
} 
untuk brand image dinyatakan valid. Sedangkan uji validitas untuk variabel label halal sebagai berikut:

Tabel IV.2

Hasil Uji Validitas Label Halal

\begin{tabular}{|c|c|c|c|}
\hline No & $\mathrm{r}_{\text {hitung }}$ & $r_{\text {tabel }}$ & Keterangan \\
\hline 1 & 0,596 & \multirow{8}{*}{$\begin{array}{l}\text { Instrumen valid jika }>r_{\text {tabel }} \\
\text { dengan } n=89 \text { pada taraf } \\
\text { signifikan } 10 \% \text { sehingga } \\
\text { diperoleh } r_{\text {tabel }} 0,1735\end{array}$} & Valid \\
\hline 2 & 0,589 & & Valid \\
\hline 3 & 0,710 & & Valid \\
\hline 4 & 0,476 & & Valid \\
\hline 5 & 0,603 & & Valid \\
\hline 6 & 0,585 & & Valid \\
\hline 7 & 0,586 & & Valid \\
\hline 8 & 0,568 & & Valid \\
\hline
\end{tabular}

Sumber: Data diolah dari hasil output SPSS 22

Dari hasil uji validitas label halal di atas pada tabel IV.2 dapat diketahui bahwa $r_{\text {hitung }}$ seluruh item pernyataan $>r_{\text {tabel }}$. Maka dapat disimpulkan bahwa seluruh item pernyataan untuk label halal dinyatakan valid. Sedangkan uji validitas untuk variabel keputusan pembelian sebagai berikut:

Tabel IV.3

Hasil Uji Validitas Keputusan Pembelian

\begin{tabular}{|c|c|c|c|}
\hline No & $r_{\text {hitung }}$ & $r_{\text {tabel }}$ & Keterangan \\
\hline 1 & 0,737 & \multirow{7}{*}{$\begin{array}{l}\text { Instrumen valid jika }>r_{\text {tabel }} \\
\text { dengan } \mathrm{n}=89 \text { pada taraf } \\
\text { signifikan } 10 \% \text { sehingga } \\
\text { diperoleh } r_{\text {tabel }} 0,1735\end{array}$} & Valid \\
\hline 2 & 0,240 & & Valid \\
\hline 3 & 0,386 & & Valid \\
\hline 4 & 0,408 & & Valid \\
\hline 5 & 0,468 & & Valid \\
\hline 6 & 0,621 & & Valid \\
\hline 7 & 0,592 & & Valid \\
\hline
\end{tabular}




\begin{tabular}{|l|l|l|l|}
\hline 8 & 0,530 & \multirow{5}{*}{} & Valid \\
\cline { 1 - 1 } 9 & 0,754 & & Valid \\
\cline { 1 - 1 } & 0,670 & & Valid \\
\hline
\end{tabular}

Sumber: Data diolah dari hasil output SPSS 22

Dari hasil uji validitas keputusan pembelian di atas pada tabel IV.3 dapat diketahu bahwa $r_{\text {hitung }}$ seluruh item pernyataan $>r_{\text {tabel }}$. Maka dapat disimpulkan bahwa seluruh item pernyataan untuk keputusan pembelian dinyatakan valid. Setelah diuji validitas, maka tahap berikutnya menguji reliabilitas dari suatu angket.

\section{Uji Reliabilitas}

Uji reliabilitas bertujuan untuk mengetahui seberapa jauh sebuah alat ukur dapat dipercaya atau diandalkan. Dengan menggunakan metode cronbach alpha $>0,6$. Berikut hasil uji reliabilitas dari variabel brand image.

\section{Tabel IV.4}

\section{Hasil Uji Reliabilitas pada Brand Image}

Reliability Statistics

\begin{tabular}{|l|l|}
\hline Cronbach's Alpha & N of Items \\
\hline .706 & 6 \\
\hline
\end{tabular}

Sumber: Data diolah dari hasil output SPSS 22

Dari hasil uji reliabilitas brand iamge di atas pada tabel IV.4 dapat dikatakan reliabel jika nilai cronbach alpha 0,706>0,60 maka dapat disimpulkan bahwa variabel brand image dinyatakan reliabel dan dapat diterima. Sedangkan uji reliabilitas untuk variabel label halal sebagai berikut.

\section{Tabel IV.5}

\section{Hasil Uji Reliabilitas pada Label Halal}

Reliability Statistics

\begin{tabular}{|l|l|}
\hline Cronbach's Alpha & N of Items \\
\hline .691 & 8 \\
\hline
\end{tabular}

Sumber: Data diolah dari hasil output SPSS 22

Dari hasil uji reliabilitas label halal di atas pada tabel IV.5 dapat dikatakan reliabel jika nilai cronbach alpha 0,691 > 0,6 maka dapat disimpulkan bahwa variabel label halal dinyatakan reliabel dan dapat diterima. Sedangkan uji reliabilitas untuk variabel keputusan pembelian sebagai berikut:

\section{Tabel IV.6}

\section{Hasil Uji Reliabilitas pada Keputusan Pembelian}

Reliability Statistics

\begin{tabular}{|l|l|}
\hline Cronbach's Alpha & N of Items \\
\hline .694 & 10 \\
\hline
\end{tabular}


Sumber: Data diolah dari hasil output SPSS 22

Dari hasil uji reliabilitas keputusan pembelian di atas pada tabel IV.6 dapat dikatakan reliabel jika nilai cronbach alpha 0,694 > 0,6. Maka dapat disimpulkan bahwa variabel keputusan pembelian dinyatakan reliabel dan dapat diterima.

\section{Analisis Data}

a) Statistik Deskriptif

Analisis deskriptif berfungsi untuk mendeskripsikan atau menggambarkan terhadap objek yang diteliti. Analisis deskriptif dalam penelitian ini dalam bentuk mean, maksimum dan minimum. Berikut hasil dari analisis deskriptif untuk uji analisis brand image, label halal dan keputusan pembelian.

\section{Tabel IV.7}

\section{Hasil Uji Deskriptif}

Descriptive Statistics

\begin{tabular}{|l|l|l|l|l|}
\hline & N & Minimum & Maximum & Mean \\
\hline Brand_Image & 89 & 17 & 30 & 24.83 \\
Label_Halal & 89 & 26 & 39 & 31.49 \\
Keputusan_Pembelian & 89 & 30 & 47 & 40.21 \\
\hline
\end{tabular}

Sumber: Data diolah dari hasil output SPSS 22

Dari hasil uji deskriptif di atas pada tabel IV.7 bahwa brand image mempunyai jumlah rata-rata sebesar 24,83 kemudian mempunyai nilai tertinggi sebesar 30 dan memiliki nilai terendah sebesar 17. Label halal mempunyai jumlah rata-rata sebesar 31,49 kemudian mempunyai nilai tertinggi sebesar 39 dan memiliki nilai terendah sebesar 26. Sedangkan keputusan pembelian mempunyai jumlah rata-rata sebesar 40,21 kemudian mempunyai nilai tertinggi sebesar 47 dan memiliki nilai terendah sebesar 30 .

b) Asumsi Dasar

1) Uji Normalitas

Uji Normalitas digunakan untuk mengetahui apakah populasi data berdistribusi normal atau tidak. Pada penelitian ini uji normalitas dilakukan dengan berdasarkan pada metode Metode uji one sample kolmogorov smirnov digunakan untuk mengetahui distribusi data, apakah mengikuti distribusi normal. Dalam hal ini untuk mengetahui apakah distribusi residual terdistribusi normal atau tidak. Residual berdistribusi normal jika nilai signifikan lebih dari 0,10 . Hal tersebut dapat dilihat pada tabel di bawah ini:

\section{Tabel IV.8}

\section{Hasil Uji One-Sample Kolmogorov-Smirnov Test}

\begin{tabular}{|ll|l|} 
One-Sample Kolmogorov-Smirnov Test & \\
\hline & & Unstandardized Residual \\
\hline $\mathrm{N}$ & & 89 \\
Normal Parameters ${ }^{\mathrm{a}, \mathrm{b}}$ & Mean & .0000000 \\
& Std. Deviation & 2.85441840 \\
Most Extreme Differences & Absolute & .074 \\
& Positive & .049 \\
& Negative & -.074 \\
Test Statistic & & .074
\end{tabular}


Asymp. Sig. (2-tailed)

$.200^{\mathrm{c}, \mathrm{d}}$

Sumber: data diolah dari output spss 22

Dari hasil uji normalitas di atas pada tabel IV.8 dapat dilihat bahwa nilai signifikansi (Asymp.Sig 2-tailed) sebesar 0,200. Jika nilai signifikansi lebih dari 0,10 $(0,200>0,10)$, maka dapat disimpulkan bahwa nilai residual tersebut berdistribusi normal.

2) Uji linearitas

Uji linearitas bertujuan untuk mengetahui apakah data variabel mempunyai hubungan yang linear secara signifikan atau tidak. Data yang baik seharusnya terdapat hubungan yang linear antara brand image, label halal, dan keputusan pembelian .

Tabel IV.9

Hasil Uji Linearitas Brand Image terhadap Keputusan Pembelian ANOVA Table

\begin{tabular}{|c|c|c|c|c|c|c|c|}
\hline & & & $\begin{array}{l}\text { Sum of } \\
\text { Squares }\end{array}$ & Df & $\begin{array}{l}\text { Mean } \\
\text { Square }\end{array}$ & $\mathrm{F}$ & Sig. \\
\hline \multirow{5}{*}{$\begin{array}{l}\text { Keputusan_p } \\
\text { embelian * } \\
\text { Brand_image }\end{array}$} & Between & (Combined) & 347.701 & 12 & 28.975 & 2.482 & .008 \\
\hline & Groups & Linearity & 301.897 & 1 & 301.897 & 25.860 & .000 \\
\hline & & $\begin{array}{l}\text { Deviation } \\
\text { from } \\
\text { Linearity }\end{array}$ & 45.804 & 11 & 4.164 & .357 & .968 \\
\hline & \multicolumn{2}{|c|}{ Within Groups } & 887.243 & 76 & 11.674 & & \\
\hline & \multicolumn{2}{|l|}{ Total } & 1234.944 & 88 & & & \\
\hline
\end{tabular}

Sumber: Data diolah dari hasil output SPSS 22

Dari hasil uji linearitas brand image di atas pada tabel IV.8 diketahui bahwa taraf signifikan pada linearitas sebesar 0,000. Berarti $0,000<0,10$ maka dapat disimpulkan bahwa antara variabel brand image terhadap keputusan pembelian terdapat hubungan yang linear.

Tabel IV.10

\section{Hasil Uji Linearitas Label Halal terhadap Keputusan Pembelian}

ANOVA Table

\begin{tabular}{|c|c|c|c|c|c|c|c|}
\hline & & & $\begin{array}{l}\text { Sum of } \\
\text { Squares }\end{array}$ & Df & $\begin{array}{l}\text { Mean } \\
\text { Square }\end{array}$ & $F$ & Sig. \\
\hline \multirow{5}{*}{$\begin{array}{l}\text { Keputusan } \\
\text { _pembelian } \\
\text { * } \\
\text { label_halal }\end{array}$} & Between & (Combined) & 515.670 & 13 & 39.667 & 4.136 & .000 \\
\hline & Groups & Linearity & 426.091 & 1 & 426.091 & 44.429 & .000 \\
\hline & & $\begin{array}{l}\text { Deviation } \\
\text { from } \\
\text { Linearity }\end{array}$ & 89.579 & 12 & 7.465 & .778 & .671 \\
\hline & Within G & oups & 719.274 & 75 & 9.590 & & \\
\hline & Total & & 1234.944 & 88 & & & \\
\hline
\end{tabular}

Sumber: Data diolah dari hasil output SPSS 22

Dari hasil uji linearitas label halal di atas pada tabel IV.9 diketahui bahwa taraf signifikan pada linearitas sebesar 0,000 . Berarti $0,000<0,10$ maka dapat disimpulkan 
bahwa antara variabel label halal terhadap keputusan pembelian terdapat hubungan yang linear.

c) Uji Asumsi Klasik

1) Uji Multikolinearitas

Uji multikolinearitas bertujuan unutuk melihat ada atau tidaknya korelasi yang tinggi antara variabel-variabel bebas dalam suatu model regresi linear berganda. Suatu model regresi dinyatakan bebas dari multikolinearitas adalah "jika nilai Variance Inflation Factor (VIF) < 10 dan nilai Tolerance $>0,1$ ".

\section{Tabel IV.11}

\section{Hasil Uji Multikolinearitas}

Coefficients $^{\mathrm{a}}$

\begin{tabular}{|c|c|c|c|c|c|c|c|}
\hline \multirow[b]{2}{*}{ Model } & \multicolumn{2}{|c|}{$\begin{array}{l}\text { Unstandardized } \\
\text { Coefficients }\end{array}$} & \multirow{2}{*}{$\begin{array}{l}\text { Standardized } \\
\text { Coefficients }\end{array}$} & \multirow[b]{2}{*}{$\mathrm{T}$} & \multirow[b]{2}{*}{ Sig. } & \multicolumn{2}{|c|}{$\begin{array}{l}\text { Collinearity } \\
\text { Statistics }\end{array}$} \\
\hline & B & $\begin{array}{l}\text { Std. } \\
\text { Error }\end{array}$ & & & & $\begin{array}{l}\text { Toleran } \\
\text { ce }\end{array}$ & VIF \\
\hline (Constant) & 12.811 & 3.491 & & 3.670 & .000 & & \\
\hline $\begin{array}{l}\text { Brand_imag } \\
\text { e }\end{array}$ & .400 & .120 & .301 & 3.319 & .001 & .823 & 1.215 \\
\hline label_halal & .555 & .109 & .461 & 5.091 & .000 & .823 & 1.215 \\
\hline
\end{tabular}

a. Dependent Variable: Keputusan_pembelian

Sumber: Data diolah dari hasil output SPSS 22

Dari hasil uji multikolinearitas di atas pada tabel IV.10, dapat diketahui bahwa nilai VIF dari variabel brand image adalah 1,215 dan variabel label halal adalah 1,215. Maka dapat disimpulkan bahwa nilai VIF dari kedua variabel di atas < 10. Sementara itu nilai tolerance untuk variabel brand image adalah 0,823 dan untuk variabel label halal adalah 0,823. Jadi dapat disimpulkan bahwa nilai tolerance dari kedua variabel di atas $>0,1$. Berdasarkan penilaian dari tabel di atas maka dapat disimpulkan bahwa tidak terjadi multikolinearitas antara variabel brand image dan label halal terhadap keputusan pembelian.

2) Uji Heteroskedastisitas

Heteroskedastisitas bertujuan untuk mengetahui apakah varian residual yang tidak sama pada semua pengamatan di dalam sebuah model regresi. Regresi yang baik seharusnya tidak terjadi heteroskedastisitas.

\section{Tabel IV.12}

\section{Hasil Uji Heteroskedastisitas correlations}

\begin{tabular}{|c|c|c|c|c|}
\hline & & $\begin{array}{l}\text { Brand_i } \\
\text { mage }\end{array}$ & $\begin{array}{l}\text { label_h } \\
\text { alal }\end{array}$ & $\begin{array}{l}\text { Unstandardized } \\
\text { Residual }\end{array}$ \\
\hline $\begin{array}{l}\text { Spearman's Brand_image } \\
\text { rho }\end{array}$ & $\begin{array}{l}\text { Correlation } \\
\text { Coefficient } \\
\text { Sig. (2-tailed) } \\
\text { N }\end{array}$ & $\begin{array}{l}1.000 \\
89\end{array}$ & $\begin{array}{l}.434^{* *} \\
.000 \\
89\end{array}$ & $\begin{array}{l}-.036 \\
736 \\
89\end{array}$ \\
\hline
\end{tabular}




\begin{tabular}{|c|c|c|c|c|}
\hline label_halal & $\begin{array}{l}\text { Correlation } \\
\text { Coefficient } \\
\text { Sig. (2-tailed) } \\
\text { N }\end{array}$ & $\begin{array}{l}.434^{* *} \\
.000 \\
89\end{array}$ & $\begin{array}{l}1.000 \\
89\end{array}$ & $\begin{array}{l}.042 \\
693 \\
89\end{array}$ \\
\hline $\begin{array}{l}\text { Unstandardized } \\
\text { Residual }\end{array}$ & $\begin{array}{l}\text { Correlation } \\
\text { Coefficient } \\
\text { Sig. (2-tailed) } \\
\text { N }\end{array}$ & $\begin{array}{l}-.036 \\
.736 \\
89\end{array}$ & $\begin{array}{l}.042 \\
.693 \\
89\end{array}$ & $\begin{array}{l}1.000 \\
89\end{array}$ \\
\hline
\end{tabular}

Correlation is significant at the 0.01 level (2-tailed).

Sumber: Data diolah dari hasil output SPSS 22

Dari hasil uji heteroskedastisitas di atas pada tabel IV.11, dapat diketahui bahwa nilai signifikan dari variabel brand image sebesar 0,1736>0,10 dan variabel label halal sebesar 0,693>0,10, maka dapat disimpulkan bahwa ke dua variabel tersebut tidak terjadi problem heteroskedastisitas.

d) Analisis Regresi Linear Berganda

Analisis regresi linear berganda digunakan untuk mengukur tingkat pengaruh brand image dan label halal terhadap keputusan pembelian. Hasil dari angket yang diberikan kepada responden masih berupa data ordinal. Peneliti mengubah data ordinal ke data interval dengan metode (MSI), selanjutnya dapat diambil karena memenuhi syarat untuk uji regresi. Uji regresi dibantu dengan SPSS versi 22 untuk mencari pengaruh antara variabel Brand Image dan Label Halal terhadap Keputusan Pembelian. Hasil uji regresi dapat dilihat pada tabel di bawah ini.

\section{Tabel IV.13}

\section{Hasil Uji Regresi Linear Berganda}

\begin{tabular}{|c|c|c|c|c|c|c|}
\hline \multicolumn{7}{|c|}{ Coefficients $^{\mathrm{a}}$} \\
\hline \multirow{2}{*}{\multicolumn{2}{|c|}{ Model }} & \multicolumn{2}{|c|}{$\begin{array}{l}\text { Unstandardized } \\
\text { Coefficients }\end{array}$} & \multirow{2}{*}{ 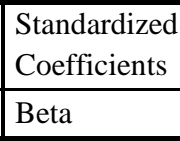 } & \multirow[b]{2}{*}{$\mathrm{t}$} & \multirow[b]{2}{*}{ Sig. } \\
\hline & & B & Std. Error & & & \\
\hline & (Constant) & 9.172 & 3.534 & & 2.595 & .011 \\
\hline & $\mathrm{BI}$ & .627 & .140 & .419 & 4.497 & .000 \\
\hline & LH & .431 & .145 & .277 & 2.970 & .004 \\
\hline
\end{tabular}

a. Dependent Variable: Keputusan_Pembelian

Sumber: Data diolah dari hasil output SPSS 22

Dari hasil uji regresi linear berganda pada tabel IV.12 di atas, maka persamaan regresi yang digunakan adalah:

$\mathrm{KP}=9,172+0,627 \mathrm{BI}+0,431 \mathrm{LH}$

Dari persamaan regresi di atas dapat diartikan bahwa:

1) Nilai Konstanta adalah sebesar 9,172 satuan menyatakan bahwa jika Brand Image dan Label Halal diasumsikan 0 maka Keputusan Pembelian kosmetik wardah bertambah sebesar 9,172 satuan.

2) Angka Koefisien regresi Brand Image adalah sebesar 0,627 satuan. Artinya jika Brand Image diasumsikan naik satuan dengan Label Halal diasumsikan 0 maka Keputusan Pembelian kosmetik wardah mengalami peningkatan sebesar 0,627 satuan. 
3) Angka Koefisien regresi Label Halal adalah sebesar 0,431 satuan. Artinya jika Label Halal diasumsikan naik satuan dengan Brand Image diasumsikan 0 maka Keputusan Pembelian kosmetik wardah mengalami peningkatan sebesar 0,431 satuan.

e) Uji Hipotesis

1) Uji koefisien Determinasi

Koefisien determinasi $\left(\mathrm{R}^{2}\right)$ pada intinya mengukur seberapa jauh kemampuan model dalam menerangkan variasi variabel terikat.

\section{Tabel IV.14}

\section{Hasil Koefisien Determinasi}

Model Summary ${ }^{b}$

\begin{tabular}{|l|l|l|l|l|l|}
\hline Model & $\mathrm{R}$ & R Square & $\begin{array}{l}\text { Adjusted } \\
\text { Square }\end{array}$ & $\begin{array}{l}\text { Std. Error of } \\
\text { the Estimate }\end{array}$ & Durbin-Watson \\
\hline 1 & $.569^{\mathrm{a}}$ & .324 & .308 & 1.97049 & 1.869 \\
\hline
\end{tabular}

a. Predictors: (Constant), Label_Halal, Brand_Image

b. Dependent Variable: Keputusan_Pembelian

Sumber: Data diolah dari hasil output SPSS 22

Dari hasil koefisien determinasi di atas pada tabel IV.13, dapat dilihat bahwa nilai $\mathrm{r}=0,569$ maka terjadi hubungan yang kuat antara variabel independen terhadap variabel dependennya. Dapat diketahui bahwa nilai Adjusted $\mathrm{R}^{2}$ sebesar 0,308 atau 30.8\% variabel brand image dan label halal mempengaruhi keputusan pembelian. Hal ini menunjukkan bahwa brand image dan label halal memberikan kontribusi terhadap keputusan pembelian sebesar 30,8\% dan sisanya 69,2\% dipengaruhi oleh faktor-faktor lain diluar penelitian yang dilakukan oleh peneliti.

2) Uji Parsial (Uji t)

Uji t digunakan untuk mengetahui apakah model regresi variabel brand image dan label halal secara parsial berpengaruh signifikan terhadap variabel keputusan pembelian. Adapun hasil analisis regresi sebagai berikut:

\section{Tabel IV.15}

\section{Hasil Uji parsial (Uji t)}

Coefficients $^{\mathbf{a}}$

\begin{tabular}{|c|c|c|c|c|c|}
\hline \multirow[b]{2}{*}{ Model } & \multicolumn{2}{|c|}{$\begin{array}{l}\text { Unstandardized } \\
\text { Coefficients }\end{array}$} & \multirow{2}{*}{$\begin{array}{l}\text { Standardized } \\
\text { Coefficients } \\
\text { Beta }\end{array}$} & \multirow[b]{2}{*}{$\mathrm{T}$} & \multirow[b]{2}{*}{ Sig. } \\
\hline & B & Std. Error & & & \\
\hline $1 \quad$ (Constant) & 9.172 & 3.534 & & 2.595 & .011 \\
\hline Brand_Image & .627 & .140 & .419 & 4.497 & .000 \\
\hline Label_Halal & .431 & .145 & .277 & 2.970 & .004 \\
\hline
\end{tabular}

a. Dependent Variable: Keputusan_Pembelian

Sumber: Data diolah dari hasil output SPSS 22

Dari hasil uji parsial di atas pada tabel IV.14, dapat dilihat bahwa $t_{\text {hitung }}$ untuk variabel brand image adalah 4,497 dan untuk tabel diperoleh dari rumus df $=\mathrm{n}-\mathrm{k}-1$ atau 89-2-1 = 86, hasil yang diperoleh untuk $t_{\text {tabel }}$ sebesar 1,663 maka Ha diterima. sedangkan thitung untuk variabel label halal adalah 2,970 > 1,663 maka Ha diterima. Maka dapat 
disimpulkan bahwa terdapat pengaruh brand image dan label halal yang signifikan terhadap keputusan pembelian.

3) Uji Simultan (Uji F)

Uji F digunakan untuk menguji pengaruh dari variabel brand image dan label halal secara keseluruhan terhadap variabel keputusan pembelian.

\section{Tabel IV.16}

\section{Hasil Uji Simultan (Uji F)}

ANOVA $^{\mathrm{a}}$

\begin{tabular}{|ll|l|l|l|l|l|}
\hline \multicolumn{2}{|l|}{ Model } & Sum of Squares & Df & Mean Square & F & Sig. \\
\hline 1 & Regression & 159.842 & 2 & 79.921 & 20.583 & $.000^{\mathrm{b}}$ \\
& Residual & 333.925 & 86 & 3.883 & & \\
& Total & 493.767 & 88 & & & \\
\hline
\end{tabular}

Sumber: Data diolah dari hasil output SPSS 22

Dari hasil uji simultan di atas pada tabel IV.15, diperoleh nilai signifikan $<\mathrm{a}(0,000$

$<0,10)$ dan $\mathrm{F}_{\text {hitung }} 20,583>\mathrm{F}_{\text {tabel }} 2,37$ (df = n-k-1 atau 89-2-1 = 86), karena $\mathrm{F}_{\text {hitung }}>$

$\mathrm{F}_{\text {tabel }}$ maka $\mathrm{H}_{0}$ ditolak dan $\mathrm{H}_{\mathrm{a}}$ diterima, artinya ada pengaruh antara brand image dan label halal secara bersama-sama (simultan) terhadap keputusan pembelian.

\section{A. Pembahasan Hasil Penelitian}

Penelitian ini berjudul pengaruh Brand Image dan Label Halal terhadap Keputusan Pembelian Kosmetik Wardah pada Mahasiswi Jurusan Ekonomi Syariah Fakultas Ekonomi dan Bisnis Islam IAIN Padangsidimpuan, diolah dengan menggunakan program komputer SPSS Versi 22. Berdasarkan hasil analisis regresi yang dilakukan pada penelitian ini diperoleh persamaan regresi yaitu:

$$
\mathrm{Y}=9,172+0,627 \mathrm{BI}+0,431 \mathrm{LH}
$$

Persamaan regresi tersebut dapat di jelaskan sebagai berikut:

Konstanta sebesar 9,172 satuan, menyatakan bahwa jika variabel Brand Image diasumsikan naik satuan dengan Label Halal diasumsikan 0 maka keputusan pembelian kosmetik wardah sebesar 9,172 satuan. Koefisien regresi variabel Brand Image adalah sebesar 0,627 satuan, artinya jika Brand Image diasumsikan naik satuan dengan Label Halal diasumsikan 0 maka Keputusan Pembelian kosmetik wardah mengalami peningkatan sebesar 0,627 satuan. Koefisien regresi variabel Label Halal adalah sebesar 0,431 satuan, artinya jika Label Halal diasumsikan naik satuan dengan Brand Image diasumsikan 0 maka Keputusan Pembelian kosmetik wardah mengalami peningkatan sebesar 0,431 satuan.

Uji koefisien determinasi membuktikan bahwa variabel brand image dan label halal memberikan kontribusi terhadap variabel keputusan pembelian sebesar 30,8\% dan sisanya $69,2 \%$ dipengaruhi oleh faktor-faktor lain diluar penelitian yang dilakukan oleh peneliti.

Secara parsial variabel brand image berpengaruh terhadap keputusan pembelian dengan nilai $t_{\text {hitung }}>\mathrm{t}_{\text {tabel }}(4,497>1,663)$, dan hal ini sesuai dengan pendapat Etta Mamang Sangadji dan Sopiah, bahwa brand image berkaitan dengan keputusan pembelian adalah seperangkat ingatan yang ada di benak konsumen mengenai sebuah merek, baik itu positif maupun negatif. 
Ingatan terhadap sebuah merek dapat berupa atribut produk dan manfaat yang di rasakan oleh konsumen. Hasil penelitian ini sejalan dengan penelitian yang dilakukan oleh Selfi Stefani yang meneliti tentang keputusan pembelian produk kosmetik wardah menyatakan bahwa iklan televisi, celebrity endorser, kualitas produk dan citra merek memiliki pengaruh terhadap keputusan pembelian. Hasil penelitian ini juga didukung oleh penelitian yang dilakukan Brian Gumelar yang menyatakan bahwa brand image memiliki pengaruh yang positif terhadap keputusan pembelian.

Secara parsial variabel label halal berpengaruh terhadap keputusan pembelian dengan nilai $\mathrm{t}_{\text {hitung }}>\mathrm{t}_{\text {tabel }}(2,970>1,663)$. Artinya terdapat pengaruh variabel label halal secara signifikan terhadap keputusan pembelian. Hal ini sesuai dengan pendapat Diana Candra Dewi, pencantuman label halal merupakan jaminan bahwa makanan dan minuman serta obat-obatan dan kosmetik yang diberi label tersebut adalah halal menurut Syariat Islam dan merupakan tanggungjawab produsen yang memproduksi produk tersebut. Akan tetapi jika pencantuman label halal menjadi tanggungjawab produsen sepenuhnya tanpa memalui pemeriksaan oleh pihak yang berwenang, maka akan sangat membahayakan konsumen karena konsumen berada dalam pihak yang sangat lemah dan kritis, hal ini sangat bertentangan dengan aturan perlabelan yang berlaku di seluruh dunia. Jadi dapat di simpulkan bahwa pencatuman sebuah label halal harus sesuai menurut syariat Islam, bagi pihak produsen harus memenuhi pemeriksaan dan sertifikasi halal oleh pihak yang berwenang seperti LPPOM-MUI sebagai lembaga yang memelopori pemberian sertifikat halal. Hasil penelitian ini sejalan dengan penelitian yang dilakukan oleh Jessi Kemala yang menyatakan bahwa terdapat pengaruh yang kuat anatara label halal dengan keputusan menggunakan produk kosmetik. Hasil penelitian ini juga didukung oleh penelitian yang dilakukan Wahyu Budi Utami yang menyatakan bahwa label halal mempunyai pengaruh yang signifikan terhadap keputusan pembeli.

Hasil uji F menyatakan bahwa ada pengaruh secara simultan antara variabel brand image dan label halal dengan variabel keputusan pembelian dengan nilai $F_{\text {hitung }} 20,583>F_{\text {tabel }} 2,37$ Dapat diartikan bahwa ada pengaruh yang signifikan antara brand image dan label halal secara bersama-sama berpengaruh terhadap keputusan pembelian. Hasil penelitian ini sejalan dengan penelitian yang dilakukan Maya Anggraeni yang menyatakan bahwa terdapat pengaruh persepsi label halal, brand image, dan word of mouth secara simultan terhadap minat beli ulang produk.

\section{KESIMPULAN DAN SARAN}

Berdasarkan hasil penelitian yang dilakukan pada bab sebelumnya, maka dapat disimpulkan sebagai berikut:

1. Secara parsial ada pengaruh Brand Image Terhadap Keputusan Pembelian Kosmetik Wardah pada Mahasiswi Jurusan Ekonomi Syariah Fakultas Ekonomi dan Bisnis Islam IAIN Padangsidimpuan, hal tersebut dapat dibuktikan dengan melihat nilai $\mathrm{t}_{\text {hitung }}>\mathrm{t}_{\text {tabel }}$ $\left(4,497\right.$ > 1,663) maka $\mathrm{H0}$ ditolak dan $\mathrm{Ha}_{1}$ diterima.

2. Secara parsial ada pengaruh Label Halal terhadap Keputusan Pembelian Kosmetik Wardah pada Mahasiswi Jurusan Ekonomi Syariah Fakultas Ekonomi dan Bisnis Islam IAIN 
Padangsidimpuan, hal tersebut dibuktikan dengan melihat nilai $\mathrm{t}_{\text {hitung }}>\mathrm{t}_{\text {tabel }}(2,970>$ 1,663) maka $\mathrm{H} 0$ ditolak dan $\mathrm{Ha}_{2}$ diterima.

3. Secara bersama-sama (simultan) ada pengaruh Brand Image dan Label Halal terhadap Keputusan Pembelian Kosmetik Wardah pada Mahasiswi Jurusan Ekonomi Syariah Fakultas Ekonomi dan Bisnis Islam IAIN Padangsidimpuan, hal tersebut dibuktikan dari $\mathrm{F}_{\text {hitung }}>\mathrm{F}_{\text {tabel }}(20,583>2,37)$, maka $\mathrm{H} 0$ ditolak dan $\mathrm{Ha}_{3}$ diterima.

Berdasarkan kesimpulan di atas, maka saran-saran yang dapat diberikan peneliti sebagai berikut:

1. Kepada perusahaan PTI, disarankan untuk tetap mempertahankan produknya yaitu dikhususkan pada produk kosmetik wardah, karena produk kosmetik yang berlabel halal pada saat ini sangat penting sekali terutama di Indonesia.

2. Bagi peneliti selanjutnya, disarankan untuk menggunakan faktor-faktor lain yang dapat mempengaruhi keputusan pembelian seperti harga, promosi, kualitas produk, dan lain sebagainya. Peneliti selanjutnya juga diharapkan objek penelitiannya tidak hanya produk yang halal saja akan tetapi bisa juga dalam perbandingan produk yang berlabel halal dengan produk yang tidak berlabel halal.

\section{DAFTAR PUSTAKA}

Agus Sucipto, Studi Kelayakan Bisnis: Analisis Integratif dan Studi Kasus, Malang: UIN-Maliki Press, 2010.

Azhari Akmal Tarigan, dari Etikake Spiritual Bisnis, Cet. Pertama, Yogyakarta: IAIN PRESS, 2014.

Briyan Gumelar "Pengaruh Brand Image dan Celebrity Endorser Terhadap Keputusan Pembelian Kosmetik Wardah (Studi pada Mahasiswi Si Universitas Negeri Yogyakarta), Skripsi, Fakultas Ekonomi Negeri Yogyakarta".

Casavera, 15 Kasus Sengketa Merek di Indonesia, Edisi Pertama, Yogyakarta: Graha Ilmu, 2009. , 8 Kasus Sengketa Merek di Indonesia, Edisi Pertama, Yogyakarta: Graha Ilmu, 2009.

Departemen Agama, Al-Quran Terjemahan dan Asbabun Nuzul, Surakarta: CV. Al-Hanan.

Diana Cadra Dewi, Rahasia di Balik Makanan Haram, Malang: UIN-Malang Press, 2007.

Duwi Priyatno, SPSS 22 Pengolahan Data Terpraktis, Yogyakarta: CV. Andi Offset, 2014.

Etta Mamang Sangadji dan Sopiah, Perilaku Konsumen: Pendekatan Praktis Disertasi Himpunan Jurnal Penelitian, Yogyakarta: CV. Andi Offset, 2013.

Fransisca Paramitasari Musay "Pengaruh Brand Image Terhadap Keputusan Pembelian (Survei pada Konsumen Kfc Kawi Kalang), Jurnal, Fakultas Ilmu Administrasi Universitas Brawijaya".

Husein Umar, Metode Penelitian untuk Skripsi dan Tesis Bisnis, Jakarta: Rajawali Pers, 2013. 


\section{Http://Www.Halalmui.Org}

\section{Http://Www.Lppommui.Org}

http://sp2010.bps.go.id/index.php/site/tabel?tid=321,

Ika Yunia Fauzia dan Abdul Kadir Riyadi, Prinsip Dasar Ekonomi Islam: Perspektif Maqasbid Al-Syariah, Jakarta: Kencana Prenadamedia Group, 2014.

Jessi Kemala Astuti "Pengaruh Label Halal Terhadap Keputusan Menggunakan Produk Kosmetk: Studi pada Mahasiswi Prodi Muamalat Fakultas Syariah dan Hukum UIN Jakarta, Skripsi, Fakultas Syariah Dan Hukum UIN Syarif Hidayatullah Jakarta, 2011”.

Juliansyah Noor, Metodologi Penelitian: Skripsi, Tesis, Disertasi, dan Karya Ilmiah, Edisi Pertama, Jakarta: Kencana Prenada Media Group, 2011.

Kasmir, Kewirausahaan, Jakarta: PT. Raja Grafindo Persada, 2006.

Leon G Schiffman dan Leslie Lazar Kanuk, Perilaku Konsumen, Jakarta: PT. Indeks, 2004.

M. Suyanto, Marketing Strategy Top Brand Indonesia, Yogyakarta: CV. Andi Offset, 2007.

Mahmud Machfoedz, Pengantar Bisnis Modern, Edisi Pertama, Yogyakarta: CV. Andi Offset, 2007.

Maya Anggraeni, "Pengaruh Persepsi Label Halal, Brand Image, dan Word Of Mouth Terhadap Minat Beli Ulang Produk (Studi Kasus pada Restoran Solaria Ambarukmo Plaza Yogyakarta), Skripsi, Fakultas Ekonomi Universitas Negeri Yogyakarta, 2016”.

Maman Abdurrahman dan Sambas Ali Muhidin, Panduan Praktik Memahami Penelitian, Bandung: CV. Pustaka Setia, 2011.

Mardani, Ayat-Ayat dan Hadis Ekonomi Syariah, Cet. Pertama, Jakarta: Rajawali Pers, 2011.

Muhammad Djakfar, Hukum Bisnis: Membangun Wacana Integrasi Perundangan Nasional dengan Syariah, Malang: UIN- Malang Press, 2009.

Muhammad Firdaus, Ekonometrika Suatu Pendekatan Aplikatif, Cet. Pertama, Jakarta: PT. Bumi Aksara, 2004.

Mudrajad Kuncoro, Metode Riset untuk Bisnis dan Ekonomi, Edisi ke 4, Jakarta: Erlangga, 2013.

Morissan, Periklanan: Komunikasi Pemasaran Terpadu, Edisi Pertama, Jakarta: Kencana Prenada Group, 2010.

Nembah F. Hartimbul Ginting, Manajemen Pemasaran, Bandung: CV. Yrama Widya, 2011.

Nugroho J. Setiadi, Business Economics and Managerial Decision Making: Aplikasi Teori Ekonomi dan Pengambilan Keputusan Manajerial dalam Dunia Bisnis, Jakarta: Kencana, 2008. 
, Prilaku Konsumen: Perspektif Kontemporer pada Motof, Tujuan, dan Keinginan Konsumen, Jakarta: kencana, 2003.

Nur Asnawi dan Masyhuri, Metodologi Riset Manajemen Pemasaran: Disertai dengan Contoh Hasil Penelitian, Malang: UIN-Maliki Press, 2011.

Nur Rianto Al-Arif, Dasar-Dasar Ekonomi Islam, Solo: PT. Era Adicitra Intermedia, 2011.

Pandji Anoraga, Manajemen Bisnis, Cet. Ke 4, Jakarta: PT. Rineka Cipta, 2009.

Rosady Ruslan, Manajemen Public Relations dan Media Komunikasi: Konsepsi dan Aplikasi, Jakarta: Raja Grafindo Persada, 2005.

, Metode Penelitian: Public Relations dan Komunikasi, Jakarta: Raja Grafindo Persada, 2004.

Setiawan dan Dwi Endah Kusrini, Ekonometrika, Yogyakarta: CV. Andi Offset, 2010.

Selfi Stefani "Analisis Pengaruh Iklan Televisi, Celebrity Endorser, Kualitas Produk, dan Citra Merek Terhadap Keputusan Pembelian pada Produk Kosmetik Berlabel Halal Wardah (Studi Kasus pada Mahasiswi UIN Syarif Hidayatullah Jakarta), Skripsi, Fakultas Ekonomi dan Bisnis UIN Syarif Hidayatullah Jakarta, 2013".

Singgih Santoso, Statistik Deskriptif: Konsep dan Aplikasi Dengan Microsoft Excel dan SPSS, Yogyakarta: Andi, 2003.

Suharsimi Arikunto, Manajemen Penelitian, Cet. ke 9, Jakarta: PT. Rineka Cipta, 2007. , Prosedur Penelitian: Suatu Pendekatan Praktik, Jakarta: PT. Rineka Cipta, 2013.

Sugiyono, Metode Penelitian Kuantitatif, Kualitatif dan R\&D, Cet. ke 8, Bandung: Alfabeta, 2009. , Metode Penelitian Kuantitatif, Kualitatif, dan R\&D, Cet. Ke 19, Bandung: Alfabeta, 2013.

Sunardi dan Anita Primastiwi, Pengantar Bisnis: Strategi dan Kasus, Cet. pertama, Yogyakarta: Caps , 2015.

Siregar Syofian, Statistika Deskriptif Untuk Penelitian Dilengkapi Perhitungan Manual dan Aplikasi SPSS Versi 17, Jakarta: Rajawali Pers, 2012.

Ujang Sumarwan, Perilaku Konsumen: Teori dan Penerapannya Dalam Pemasaran, Cet. Pertama, Bogor: Ghalia Indonesia, 2011.

Wahyu Budi Utami "Pengaruh Label Halal Terhadap Keputusan Membeli (Survei pada Pembeli Produk Kosmetk Wardah di Outlet Wardah Griya Muslim An-Nisa Yogyakarta), Skripsi, Fakultas Ilmu Sosial dan Humantora UIN Sunan Kalijaga Yogyakarta, 2013”. 